\title{
CHRONOLOGY OF ARMAMENTS, DISARMAMENT AND INTERNATIONAL SECURITY 2012
}

NENNE BODELL

This chronology lists the significant events in 2012 related to armaments, disarmament and international security. In addition to the headlinegrabbing events, it also records the less publicized, but no less important, advances and setbacks in arms controls and international security.

Dates are according to local time. Keywords are given in the margins. Abbreviations are explained below.

\section{January}

The Atomic Energy Organization of Iran announces that it has manufactured Iran's first domestically produced nuclear fuel rod. On 2 January Iran test-fires medium- and long-range ballistic missiles during naval exercises in the Gulf. The tension in the region grows following the new US sanctions targeting Iran's Central Bank and financial sector, imposed on 31 December 2011.

\section{January}

A 6000-8000-strong group of armed Lou Nuer fighters attacks the town of Pibor, Jonglei state, South Sudan. Personnel from the UN Mission in South Sudan (UNMISS) and the South Sudanese Army (the Sudan People's Liberation Army) deployed in the area claim that they are outnumbered by the fighters. Ethnic violence between the Lou Nuer and Murle tribes since December has left several thousand civilians dead and has displaced thousands more.

\section{January}

US President Barack Obama presents a new strategic guidance document for the Department of Defense to articulate priorities for US defence in the 21st century, including strengthening the US presences in the Asia-Pacific region and the Middle East, reducing nuclear arsenals, and strengthening intelligence, surveillance and reconnaissance, and counterterrorism capabilities.

\section{Keywords}

Iran; USA

South Sudan

USA; Military strategy 


\section{January}

Iran; Nuclear programme

Iran; Nuclear programme;

Terrorism

Nigeria; Terrorism

Arab League; Syria

UN; Somalia

Arab League; Syria
The Iranian newspaper Kayhan reports that Iran has begun uranium enrichment at a new underground site at Fordow, close to the city of Qom. The Fordow facility is smaller but more efficient than the main enrichment site at Natanz.

\section{January}

An Iranian nuclear scientist dies in Tehran in what is termed a 'terrorist bomb blast', when a magnetic explosive device attached to his car explodes. This is the fourth killing of an Iranian nuclear scientist; officials indicate that they believe that Israel is responsible.

\section{January}

At least 200 people are killed in a series of bombings and attacks carried out by the militant Islamist group Boko Haram ('Western education is forbidden') in Kano, Nigeria. The group has killed hundreds of people since its bombing of the UN headquarters in Abuja in August 2011.

\section{January}

The Arab League presents a proposal for a peace plan to end the 10-month-long conflict in Syria. Under the agreement, President Bashar al-Assad would transfer power to a deputy and start negotiations with the opposition, and a government of national unity would be formed within two months, followed by presidential and parliamentary elections. On 23 January Syria rejects the plan and calls it an infringement of its sovereignty.

\section{January}

The UN Political Office for Somalia (UNPOS) re-establishes a presence in Mogadishu, after being based in Nairobi, Kenya, since 1995.

\section{January}

The Arab League suspends its monitoring mission in Syria. This follows days of escalating violence across the country, with the army launching an offensive against opposition fighters in the suburbs of Damascus, and President Bashar al-Assad's refusal to step down and hand power to a government of national unity. 


\section{3-4 February}

Syrian Government forces attack Homs with artillery, reportedly killing UN; Syria about 300 people, in the most deadly attack since anti-government protests began in March 2011. On 4 February the UN Security Council fails to agree on a resolution to back the Arab League's proposed peace plan. Thirteen of the Council's members vote in favour of the resolution, but it is vetoed by China and Russia.

\section{February}

The UK and the USA recall their ambassadors to Syria in protest at the Syrian Government's violence against the civilian population. Government forces renew shelling Homs on 6-7 February; the Syrian National Council, the main opposition group, claims that at least 50 people are killed.

\section{February}

The Darfur Regional Authority (DRA) is inaugurated in the regional capital, Al Fashir. The DRA is intended to stimulate development and facilitate peace in Darfur; it is part of the implementation of the Doha Peace Document, signed by the Sudanese Government and a rebel group, the Liberation and Justice Movement (LJM), on 14 July 2011.

\section{February}

Officials of the governments of Sudan and South Sudan sign, in Addis Ababa, Ethiopia, a Memorandum of Understanding (MOU) on Nonaggression and Cooperation, at a meeting of the Joint Political and Security Mechanism (JPSM). The MOU calls for mutual respect of the two countries' sovereignty and territorial integrity, non-interference in each other's internal affairs and no use of force in their relations. Both the African Union and the UN welcome the agreement.

\section{February}

The UN General Assembly adopts, by a vote of 137-12 (China and Russia voting against) with 17 abstentions, a resolution strongly condemning the continuing 'widespread and systematic' human rights violations by the Syrian authorities and calling on all parties in Syria 'to stop all violence or reprisals immediately'.

\section{February}

The UN Security Council unanimously adopts Resolution 2036, requesting the African Union (AU) to increase the strength of the AU Mission in Somalia (AMISOM) to a maximum of 17731 uniformed personnel until 31 October 2012, and deciding to expand the UN logistic support package for AMISOM.

UN; Syria

Syria; UK; USA

Sudan; Darfur

South Sudan; Sudan

; 


\section{2-27 February}

ISAF; Afghanistan; USA; Islam

Somalia

North Korea; USA; Nuclear programme

Yemen; al-Qaeda

\section{February} and terrorism.

\section{February}

\section{February}

\section{March}

Following the burning of copies of the Quran at Bagram Airfield, Afghanistan, by soldiers of the NATO-led International Security Assistance Force (ISAF) on 22 February, violent protests spread throughout Afghanistan and more than 20 people are killed, including ISAF soldiers. On 23 February US President Barack Obama expresses his 'deep regret' to Afghan President Hamid Karzai in a personal letter, in which he vows to hold to account those responsible for the Bagram incident.

The UN and the Arab League appoint Kofi Annan, a former UN SecretaryGeneral, as their Joint Special Envoy for Syria. The envoy will provide good offices aimed at bringing an end to all violence and human rights violations in Syria and promoting a peaceful solution to the Syrian crisis.

Meeting at the London Conference on Somalia, delegates from Somalia, 38 other countries and the international community agree to support the Somali political process; to strengthen the African Union Mission in Somalia (AMISOM) and help Somalia develop its own security forces; to help build stability at the local level; and to step up action against pirates

Meeting in Tunis, Tunisia, foreign ministers from about 60 countries attend the International Conference of the Friends of the Syrian People. The participants agree on a declaration calling for an immediate ceasefire and halt to all violence in Syria; in response the Syrian Government allows humanitarian aid organizations to enter the country.

Following talks in Beijing, China, between North Korean and US officials, North Korea agrees to suspend its nuclear weapon tests and uranium enrichment and to allow inspectors from the International Atomic Energy Agency (IAEA) to verify and monitor activities at its main nuclear reactor, in Yongbyon, North Pyongan. North Korea also agrees to a moratorium on launches of long-range missiles. The North Korean concessions are part of a larger deal including 240000 tonnes of US food aid.

Militants from Ansar al-Sharia (Partisans of Islamic Law), which is linked to al-Qaeda in the Arabian Peninsula (AQAP), launch a suicide attack on military bases in Zinjibar, Yemen, killing over 100 soldiers and wounding many more. During the attack the militants also take soldiers hostage and capture heavy weapons. Around 30 rebels are killed. 


\section{March}

A US soldier murders and burns 16 Afghan civilians in a night-time

USA; Afghanistan attack in two villages close to the Zangabad military base, in the south of Afghanistan. The Taliban vow revenge for the 'inhumane attack'. Anti-US sentiment in Afghanistan has escalated since the burning of the Quran on 22 February.

\section{March}

In its first verdict since it was set up in 2002, the International Criminal Court (ICC) in The Hague, Netherlands, finds the leader of the Union of Congolese Patriots (Union des Patriotes Congolais, UPC), Thomas Lubanga Dyilo, guilty of war crimes. The crimes consist of enlisting and conscripting children under the age of 15 years and using them to participate actively in hostilities in the Democratic Republic of the Congo (DRC) between 2002 and 2003. Lubanga Dyilo was arrested in 2006 and went on trial in 2009. On 10 July the ICC sentences him to 14 years in prison.

\section{March}

Following violent clashes between government forces and Tuareg rebels Mali from the National Movement for the Liberation of Azawad (Mouvement National de Liberation de l'Azawad, MNLA) in northern Mali since midJanuary, President Amadou Toumani Touré is overthrown in a military coup d'état. The international community condemns the coup.

\section{March}

The UN-Arab League Joint Special Envoy for Syria, Kofi Annan, receives the formal acceptance from the Syrian Government of a six-point proposal to end the ongoing violence in the country. The plan, which was unanimously endorsed by the UN Security Council on 21 March, includes a UN-monitored ceasefire and the withdrawal of Syrian Government forces and artillery from population centres.

\section{6-27 March}

The second Nuclear Security Summit is held in Seoul, South Korea, with

Nuclear security more than 53 heads of states and international organizations participating. The summit focuses on cooperative measures to combat the threat of nuclear terrorism, the protection of nuclear materials and related facilities, and the prevention of trafficking in nuclear materials. The next Nuclear Security Summit will be held in the Netherlands in 2014.

UN; Arab League; Syria 
China; Philippines

Guinea-Bissau

UN; Arab League; Syria

$\mathrm{UN}$; Syria

Afghanistan; Terrorism

\section{April}

Following reports of Chinese fishing boats in the area of Scarborough Shoal, South China Sea, the Philippine Navy sends its largest vessel, which engages in a stand-off with Chinese maritime surveillance ships. Both countries claim that the shoal is 'an integral part' of their territory. The dispute continues into December; the Philippines calls for international support to resolve it in multilateral talks.

\section{April}

A military coup d'état ousts the civilian government of Guinea-Bissau. (See also 11 May.)

The ceasefire under the peace plan of Kofi Annan, the UN-Arab League Joint Special Envoy for Syria, takes effect, after escalated violence throughout Syria during the past week. The UN estimates that more than 9000 people have been killed during the past year's fighting. The Syrian Government claims that the rebels have killed more than 2600 security personnel.

\section{April}

To celebrate the 100th anniversary of the birth of Kim Il-Sung, the country's founder, North Korea launches a rocket that is intended to send a satellite into orbit. The rocket explodes less than two minutes after lift-off and falls into the Yellow Sea. The launch is condemned by the international community, which claims that it violates UN Security Council resolutions. Following North Korea's announcement of the planned launch, the USA had suspended planned food aid on 28 March.

\section{April}

The UN Security Council unanimously adopts Resolution 2042, authorizing the deployment of an advance team of up to 30 unarmed military observers to Syria. The team is to report on the implementation of a full cessation of armed violence, pending the deployment of a UN supervision mission to monitor the ceasefire. (See also 21 April.)

\section{April}

Taliban militants launch a coordinated attack on the diplomatic quarter and the parliament in Kabul, Afghanistan, and in three eastern provinces. A spokesman for the Taliban states that the attack is the opening of the movement's spring offensive. 


\section{April}

India successfully carries out a test flight of the Agni V, a long-range ballistic missile capable of carrying a nuclear warhead. The missile has a range of 5000 kilometres, and so is capable of reaching Beijing and Shanghai in China.

\section{April}

Following weeks of increasing violence over the disputed oil town of Heglig on the border between South Sudan and Sudan, South Sudan withdraws its troops from the area. South Sudan claims Heglig as part of its territory, but the international community has condemned the actions in the area.

\section{April}

The UN Security Council unanimously adopts Resolution 2043, authorizing the establishment of the UN Supervision Mission in Syria (UNSMIS), for an initial period of 90 days, to monitor the cessation of violence and to monitor and support the full implementation of the six-point UN peace plan. UNSMIS will comprise up to 300 unarmed military observers and 'an appropriate civilian component'.

\section{April}

After four years of hearings, the Special Court for Sierra Leone, based in the Hague, Netherlands, finds former Liberian President Charles Taylor guilty of 11 charges of aiding and abetting war crimes in Sierra Leone's 1991-2002 civil war. Taylor is the first former head of state to be convicted in an international court on war crimes since World War II. On 30 May Taylor is sentenced to 50 years imprisonment.

\section{May}

Meeting in Kabul, Afghanistan, US President Barack Obama and Afghan President Hamid Karzai sign the Afghan-US Enduring Strategic Partnership Agreement, a legally binding executive agreement defining how the partnership between the two countries will continue after the withdrawal of the US troops in 2014.

\section{May}

Following the lifting of a hold on publication, Nature publishes an article by a US research group on laboratory-derived influenza strains airborne transmissible between mammals. Science publishes a similar article by a Dutch research group on 22 June after the Netherlands issues an export licence. The question of publishing the research, which had been announced on 12 September 2011, had prompted debate in the security and life science communities about whether bioterrorism concerns outweighed the value for public health and influenza pandemic preparedness. 
USA; Terrorism

ECOWAS; Guinea-Bissau

ICTY; Bosnia and Herzegovina; War crimes

NATO; Afghanistan; BMD; Terrorism

\section{May}

The trial of Khalid Sheikh Mohammed, the alleged planner of al-Qaeda's attacks on the USA on 11 September 2001, and four other accused terrorists begins before a military tribunal at the US base at Guantánamo Bay, Cuba. The five men are charged with the murder of almost 3000 people, terrorism, hijacking, conspiracy and destruction of property.

\section{May}

Two successive explosions in Damascus kill 55 people and injure nearly 400. The Syrian Government blames what it terms 'terrorists'; the opposition accuses the government of staging the blasts. Since the ceasefire brokered by the UN-Arab League Joint Special Envoy, Kofi Annan, began in April numerous violations have been reported on both sides.

\section{May}

Following the military coup d'état in Guinea-Bissau on 12 April, the Economic Community of West African States (ECOWAS) brokers a deal setting up a transitional government. On 18 May the ECOWAS Mission in Guinea-Bissau (ECOMIB) is deployed to lead the transition back to civilian rule after the elections to be held in April 2013, assist in security sector reform and facilitate the withdrawal of the Angolan Technical and Military Assistance Mission in Guinea-Bissau (MISSANG).

\section{May}

The trial of Ratko Mladić, a Bosnian Serb military leader, begins at the International Criminal Tribunal for the former Yugoslavia (ICTY), based in The Hague, Netherlands. Mladić was arrested in May 2011 and has been charged over the 1995 Srebrenica massacre and other war crimes during the 1992-95 Bosnian War.

\section{8-19 May}

G8 Meeting in Camp David, Maryland, USA, the leaders of the Group of Eight (G8) industrialized states adopt the Camp David Declaration, which addresses the question of food security and reaffirms that non-proliferation and disarmament are top priorities for the group.

\section{0-21 May}

At its 2012 summit, held in Chicago, Illinois, USA, the North Atlantic Treaty Organization (NATO) adopts a declaration on defence capabilities, 'Toward NATO Forces 2020'; approves and makes public the results of the Deterrence and Defence Posture Review; declares that an 'interim' NATO ballistic missile defence (BMD) capability has been achieved; endorses NATO's Policy Guidelines on Counter-Terrorism; and reiterates that the ISAF combat mission in Afghanistan will close by the end of 2014, and starts planning for a post-2014 mission to assist Afghan security forces. 


\section{May}

A suicide bomb attack targets soldiers rehearsing for a military parade in Sana'a, Yemen, killing over 100 people and injuring hundreds more. Ansar al-Sharia (Partisans of Islamic Law), a militant group linked to al-Qaeda in the Arabian Peninsula (AQAP), claims responsibility for the attack in a Facebook posting, calling it a retaliation for the government campaign against al-Qaeda that began in early May.

\section{May}

Over 100 people are killed, including more than 30 children, and hundreds Syria are injured in an artillery attack by government forces on the village of Houla, Homs Governorate, Syria. On 27 May the UN Security Council unanimously condemns the killings and demands that the Syrian Government immediately ceases the use of heavy weapons in population centres.

\section{June}

The UN Supervision Mission in Syria (UNSMIS) suspends its activities because of the escalation of the violence across the country over the past 10 days. The monitors will remain at their locations in Syria until further notice but will not conduct patrols.

\section{June}

A Turkish F-4 combat aircraft is shot down by Syrian forces over the Mediterranean while conducting a training flight. Syria claims that the aircraft was flying over its territorial waters. The European Union condemn Syria for downing the aircraft. Turkey calls a NATO meeting on 26 June to discuss the incident.

\section{June}

Meeting in Geneva, Switzerland, the Action Group for Syria, chaired by the UN-Arab League Joint Special Envoy for Syria, Kofi Annan, agrees on steps and measures to be taken by the parties to the Syrian conflict in order to secure full implementation of the six-point UN peace plan and UN Security Council resolutions 2042 and 2043. The steps include an immediate cessation of violence in all its forms. The Action Group also agrees on principles and guidelines for a Syrian-led transition. Opposition groups react negatively to the agreement.

\section{2-27 July}

The UN Conference on the Arms Trade Treaty (ATT) is held at the UN headquarters in New York, USA. It ends without reaching consensus on a treaty text. On 24 December the UN General Assembly decides to hold a follow-on conference on the treaty in March 2013. 


\section{July}

Syria In an attack with mortars and artillery, Syrian Government troops and Shabiha, a pro-regime militia, kill more than 200 people, mostly civilians, in the village of Tremseh, near Hamah, Syria.

\section{July}

EU; Horn of Africa; Indian Ocean; Peace operations

Syria

Syria; CBW

Iraq; al Qaeda; Terrorism

UN; Arab League; Syria
The Council of the European Union (EU) establishes the EU Mission on Regional Maritime Capacity Building in the Horn of Africa (EUCAP Nestor) under the Common Security and Defence Policy (CSDP). The mission, which was approved in December 2011, will be a civilian mission and will complement the EU Naval Force Somalia (EUNAVFOR Somalia, Operation Atalanta) and the EU Training Mission Somalia (EUTM). Deployment starts in early September.

\section{July}

A bomb detonates at the National Security Building, Damascus, killing three top officials, including the defence minister, and injures many more. Rebels claim responsibility for the attack, which comes after several days of heavy violence in the city.

\section{July}

A spokesman of the Syrian Ministry of Foreign Affairs acknowledges for the first time that Syria possesses 'weapons of mass destruction', and in particular chemical weapons, when he states that 'All varieties of these types of weapons are stored and secured by the Syrian armed forces and under its direct supervision, and will not be used unless Syria is subjected to external aggression'. The statement was made as Syria faces international isolation and threats by Israel to invade to prevent such weapons from falling into the hands of the rebels.

At least 116 people are killed and around 300 injured in a series of coordinated gun and bomb attacks across Iraq. The Islamic State of Iraq (ISI), al-Qaeda's affiliate in Iraq, claims responsibility for the attacks, which were mostly targeted at Shia Muslims.

\section{August}

The UN-Arab League Joint Special Envoy for Syria, Kofi Annan, announces his resignation after failing to achieve a temporary ceasefire in the six months since his appointment. He claims that his peace mission has become a 'mission impossible'. On 17 August Lakhdar Brahimi, an Algerian diplomat and former UN special representative, is appointed as Annan's replacement as Joint Special Envoy. 


\section{August}

Following an attack by Islamists on an Egyptian checkpoint on the border between Sinai and Israel on 5 August, which killed 16 Egyptian soldiers, the Egyptian military launches air and ground operations against the suspected perpetrators. Egypt also closes the Rafah border crossing with the Gaza Strip until further notice, leaving the Gaza Strip largely cut off from the outside world. This is the first time since the 1973 war with Israel that the Egyptian Army fires missiles in Sinai. On 11 August Egyptian President Muhammad Morsi orders tanks to be deployed at posts along the border in Sinai.

\section{August}

Following a decision on 16 August by the UN Security Council to create a liaison office to support efforts for a political solution in Syria, the UN Supervision Mission in Syria (UNSMIS) ends at midnight. The 150 observers leave the country.

\section{August-7 September}

The second UN Conference to Review Progress Made in the UN; SALW Implementation of the Programme of Action to Prevent, Combat and Eradicate the Illicit Trade in Small Arms and Light Weapons in All Its Aspects is held in New York, USA. The parties adopt by consensus an outcome document highlighting that the international community renews its commitment to preventing, combating and eradicating the illicit trade in small arms and light weapons.

\section{1-14 September}

Protesters against a film seen as insulting the Islamic prophet Muhammad attack the US Embassy in Cairo, Egypt. On 12 September the US Consulate in Benghazi, Libya, is attacked by gunmen and US diplomatic personnel are killed. The protests spread across the Arab world, and Western embassies are attacked in several countries on 14 September.

\section{1-17 September}

Following the Japanese Government's announcement that it has bought three of the Senkaku Islands (called the Diaoyu Islands in China) in the East China Sea from a private owner, the territorial dispute between China and Japan over the islands escalates. Chinese marine patrol ships enter Japanese-claimed waters around the islands. Large demonstrations against Japan take place across China, and on 17 September Japanese companies in China close factories and offices.

\section{September}

The Conference on Disarmament (CD) concludes its 2012 session without CD; Arms control any substantive negotiations on a fissile material cut-off treaty (FMCT). 
South Sudan; Sudan

Kenya; Somalia; Peace operations

Syria; Turkey

Philippines

Russia; USA; Disarmament

\section{September}

Meeting in Addis Ababa, Ethiopia, under the auspices of the African Union High-level Implementation Panel and the UN Security Council, the presidents of South Sudan and Sudan sign a cooperation agreement, the Addis Ababa Agreement. The agreement commits the two countries to implementing a series of arrangements dealing with issues including security, the management of oil resources and border demarcation.

\section{September}

Kenyan troops, operating as part of the African Union Mission in Somalia (AMISOM), launch an air and sea attack on Kismayo, Somalia, the last stronghold of the Islamist movement al-Shabab. After heaving fighting, al-Shabab withdraws from the city.

\section{3-4 October}

After a mortar bomb is fired across the border from Syria into Turkish territory, killing Turkish civilians, the Turkish military strikes target inside Syria. In an emergency meeting held later that day to discuss the escalating Syrian conflict, NATO ambassadors condemn the Syrian attack and Turkey makes a formal complaint to the UN. On 4 October the UN Security Council unanimously approves a statement condemning Syria's shelling of a Turkish town. On the same day, the Turkish Parliament gives its military legal authority to launch cross-border strikes into Syria in response to the attack.

\section{October}

Meeting in Kuala Lumpur, Malaysia, the Philippine Government and the Moro Islamic Liberation Front (MILF) reach a framework peace agreement under which a new region, named Bangsamoro, on part of the island of Mindanao with a mainly Muslim population, will be given considerably autonomy. The Philippine Government will retain control over defence, foreign policy and broad economic policy. The deal ending a 40-year conflict is signed in Manila, Philippines, on 15 October.

\section{October}

The Russian Government announces that it will not renew the Cooperative Threat Reduction (CTR) programme (also known as the Nunn-Lugar programme) when it expires in early 2013. The programme, under which Russia and the USA safeguard and dismantle nuclear and chemical weapons in the former USSR, has been running since 1992. 


\section{October}

A Syrian passenger aircraft travelling from Moscow, Russia, to Damacus, Syria, and suspected of carrying military equipment is intercepted by Turkish combat aircraft and forced to land at Ankara Airport. In 2011 Turkey stated that it would be willing to take measures to 'stop and confiscate' any shipment of military supplies, by air or sea, to Syria in contravention of Turkey's unilateral arms embargo.

\section{October}

The UN Security Council requests that the Africa Union, the Economic Community of West African States (ECOWAS) and the UN SecretaryGeneral present a plan within 45 days to deploy a military force to counter the Islamist rebellion in northern Mali, should diplomacy fail.

\section{October}

Meeting in Hurdal, Norway, the Colombian Government and the Revolutionary Armed Forces of Colombia (Fuerzas Armadas Revolucionarias de Colombia, FARC) formally start negotiations aiming at ending the conflict that began in 1964. Three earlier attempts have failed.

\section{October}

The Yarmouk military-industrial complex in Khartoum, Sudan, is bombed by four aircraft, causing a huge explosion. Sudanese officials blame Israel for the attack and state that 'Sudan reserves the right to strike back at Israel'. Israel does not comment on the accusations.

\section{November}

At an emergency meeting in Abuja, Nigeria, the leaders of the Economic Community of West African States (ECOWAS) member states agree to deploy a 3300-strong military force to counter the Islamist rebellion in northern Mali. The Africa Union approves the plan on 13 November. Although the UN Security Council had requested that such a plan be presented by 25 November, on 28 November the UN Secretary-General, Ban Ki-moon, states that the plan needs to be developed further on 'fundamental questions' on how the force will be led, trained and equipped; nonetheless, he recommends that the Security Council approves the deployment. (See also 20 December.)

\section{November}

The members of the Gulf Cooperation Council (GCC) recognize the National Coalition of Syrian Revolutionary and Opposition Forces as the legitimate representative of the Syrian people. France, the first Western country to recognize the coalition, does so on 13 November and states that it is considering providing arms to the rebel group. On 15 November Turkey also officially recognizes the coalition.
Syria; Turkey

UN; AU; ECOWAS; Mali;

Peace operations

Colombia

Israel; Sudan

UN; AU; ECOWAS; Mali;

Peace operations

GCC; France; Turkey; Syria 
Israel; Gaza Strip

$\mathrm{UN}$; DRC

Syria

UN; Palestine

\section{4-21 November}

Israel launches aerial attacks on the Gaza Strip, killing among others Ahmed Jabari, Hamas's top military commander. The attack follows continued Palestinian rocket fire into Israel from the Gaza Strip since Hamas withdrew from its unilateral ceasefire in October. The Israeli attack escalates the hostilities with Hamas, and Israel prepares for a ground invasion of the Gaza Strip. The violence is condemned by the international community, and the UN Secretary-General, Ban Ki-moon, calls for an immediate ceasefire. Following intensive negotiations in Cairo, Egypt, mediated by Egyptian President Muhammad Morsi, a ceasefire agreement between Israel and Hamas is announced on 21 November. More than 160 people are killed during the eight days of fighting.

\section{5-20 November}

Fighting between the Congolese armed forces (Forces armées de la République démocratique du Congo, FARDC) and the 23 March Movement (Mouvement du 23 mars, M23) rebel group erupts in eastern Democratic Republic of the Congo (DRC), breaking a three-month ceasefire. Rwanda and Uganda are accused of aiding M23 but strongly deny it. After the UN Stabilization Mission in the DRC (MONUSCO) fails to stop the rebels from advancing, M23 captures Goma, the largest city in eastern DRC, on 20 November, without resistance. M23 was formed in April 2012 by soldiers deserting from the FARDC.

\section{November}

At the 21st ASEAN Summit, held in Phnom Penh, Cambodia, the leaders of the Association of Southeast Asian Nations (ASEAN) launch the ASEAN Institute for Peace and Reconciliation (AIPR). The institute will review ASEAN's cooperation on conflict resolution and aims to contribute to peace and reconciliation in South East Asia.

\section{November}

Dozens of people, mostly civilians, are killed in four consecutive explosions in Damascus, Syria. The Syrian Government and the opposition blame each other for the attacks.

\section{November}

The UN General Assembly adopts, by a vote of 138-9 with 41 abstentions, a resolution granting Palestine non-member state status at the UN. Israel and the USA are among those voting against. Previously, the Palestine Liberation Organization (PLO) held permanent observer status. Palestine's enhanced status as a non-member state will permit it to participate, but not vote, in UN General Assembly debates and to apply to join UN agencies and the International Criminal Court (ICC). 


\section{December}

An international peace initiative for a resumption of dialogue between the government and Kurds in Turkey is launched in Brussels, Belgium.

\section{December}

The rebel coalition Séléka launches an offensive with the aim of overthrowing President François Bozize of the Central African Republic. On 11 January 2013, after several days of negotiations, a ceasefire agreement is signed in Libreville, Gabon, under which a government of national unity is to be created.

\section{December}

North Korea successfully launches a Unha-3 rocket. According to the Canadian-US North American Aerospace Defense Command (NORAD), the rocket 'deployed an object that appeared to achieve orbit'. The launch is immediately condemned by the international community. The UN Secretary-General, Ban Ki-moon, states that it is a violation of UN Security Council Resolution 1874 (2009), which demands that North Korea conducts no launch using ballistic missile technology. North Korea has previously made four failed attempts to launch long-range missiles. (See also 13 April.)

\section{7-19 December}

Nine health workers on a polio vaccination programme are shot dead in a series of attacks in Pakistan. Rumours that immunization campaigns are cover for spies have circulated since Pakistani vaccination workers were used to gather intelligence prior to the USA's assassination of Osama bin Laden in Abbottabad on 1 May 2011. The polio vaccination programme is suspended in Sindh and Khyber Pakhtunkhwa provinces.

\section{December}

The UN Security Council unanimously adopts Resolution 2085, under Chapter VII of the UN Charter, authorizing the deployment of an Africanled International Support Mission in Mali (AFISMA), as agreed by the Economic Community of West African States (ECOWAS) on 11 November, 'to provide coordinated and coherent support to the ongoing political and security processes in the country'. The Council also emphasizes 'the need to further refine planning before the start of an offensive military operation'.

\section{December}

The UN Security Council Sanctions Committee on the Democratic Republic of the Congo (DRC) adds the 23 March Movement (Mouvement du 23 mars, M23) rebel group and its alleged Rwandan allies, the FDLR (Forces démocratiques de libération du Rwanda, Democratic Forces for the Liberation of Rwanda), to the list of groups subject to an arms embargo and other sanctions in the eastern DRC.
Turkey; Kurds

Central African Republic

North Korea; Missiles

Pakistan; Health; Terrorism

UN; ECOWAS; Mali; Peace operations

UN; DRC; Arms embargoes 
SIPRI is an independent international institute dedicated to research into conflict, armaments, arms control and disarmament. Established in 1966, SIPRI provides data, analysis and recommendations, based on open sources, to policymakers, researchers, media and the interested public.

\section{GOVERNING BOARD}

Göran Lennmarker, Chairman (Sweden)

Dr Dewi Fortuna Anwar (Indonesia)

Dr Vladimir Baranovsky (Russia)

Ambassador Lakhdar Brahimi (Algeria)

Jayantha Dhanapala (Sri Lanka)

Susan Eisenhower (United States)

Ambassador Wolfgang Ischinger (Germany)

Professor Mary Kaldor (United Kingdom)

The Director

\section{DIRECTOR}

Professor Dr Tilman Brück (Germany)

\section{ABBREVIATIONS}

$\begin{array}{ll}\text { ASEAN } & \text { Association of Southeast Asian Nations } \\ \text { AU } & \text { African Union } \\ \text { BMD } & \text { Ballistic missile defence } \\ \text { CBW } & \text { Chemical and biological warfare } \\ \text { DRC } & \text { Democratic Republic of the Congo } \\ \text { ECOWAS } & \text { Economic Community of West African States } \\ \text { EU } & \text { European Union } \\ \text { G8 } & \text { Group of Eight industrialized states } \\ \text { GCC } & \text { Gulf Cooperation Council } \\ \text { ICC } & \text { International Criminal Court } \\ \text { ICTY } & \text { International Criminal Tribunal for the former Yugoslavia } \\ \text { ISAF } & \text { International Security Assistance Force } \\ \text { NATO } & \text { North Atlantic Treaty Organization } \\ \text { SALW } & \text { Small arms and light weapons } \\ \text { UN } & \text { United Nations }\end{array}$

Other abbreviations are defined in the text.

\section{ABOUT THE AUTHOR}

Nenne Bodell (Sweden) is Director of the SIPRI Library and Documentation Department and of the SIPRI Arms Control and Disarmament Documentary Survey.

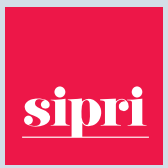

STOCKHOLM INTERNATIONAL PEACE RESEARCH INSTITUTE Signalistgatan 9 SE-169 70 Solna, Sweden Telephone: +4686559700 Fax: +4686559733 